\title{
Trends in gastroenteritis-associated mortality in the United States, 1985-2005: variations by ICD-9 and ICD-10 codes
}

Jyotsna S Jagai ${ }^{1,4^{*}}$, Genee S Smith², Judith E Schmid ${ }^{3}$ and Timothy J Wade ${ }^{4}$

\begin{abstract}
Background: Trends in gastroenteritis-associated mortality are changing over time with development of antibiotic resistant strains of certain pathogens, improved diagnostic methods, and changing healthcare. In 1999, ICD-10 coding was introduced for mortality records which can also affect trends. We assess trends in gastroenteritis-associated mortality and changes associated with coding.
\end{abstract}

Methods: Trends in gastroenteritis-associated mortality rates in the United States were examined using the National Center for Health Statistics Multiple Cause-of-Death Mortality databases for 1985-2005. All deaths with the underlying cause or any contributing cause included gastroenteritis were included. Cases were selected based on ICD9 (pre-1999) and ICD10 (1999-2005) codes and all analyses were stratified by ICD usage. Annual trends in age adjusted mortality rates were assessed using linear regression spline analysis. Relative risks and 95\% confidence intervals (Cls) were calculated using Poisson regression adjusted for age group, sex, race, and region.

Results: There were a total of 190,674 deaths related to gastroenteritis in the U.S. from 1985-2005 with an average of 9,080 per year. During this time the percent of deaths related to gastroenteritis more than tripled, increasing from $0.25 \%$ to $0.80 \%$ of all deaths. Though the time periods varied in length, we demonstrate a significant increase in slope from a 0.0054\% annual increase during the period 1985-1998, when ICD-9 coding was used, to a 0.0550\% annual increase during 1999-2005, when ICD-10 coding was used. For both time periods, the oldest age group (75+ years) demonstrated the highest risk of death due to gastroenteritis. Additionally, males demonstrated higher risk than females and blacks were at higher risk than whites for death due to gastroenteritis.

Conclusions: This analysis demonstrates the public health burden of gastroenteritis-associated mortality in the United States and changes in trends due to change from ICD-9 to ICD-10 coding. The overall rate of gastroenteritis-associated mortality has more than tripled over the 21-year period from 1985 to 2005 and the primary burden of deaths due to gastroenteritis is in the elderly population.

Keywords: Gastroenteritis, Mortality, Intestinal infections

\footnotetext{
*Correspondence: jjagai2@uic.edu

${ }^{1}$ School of Public Health, Division of Environmental and Occupational Health

Sciences, University of Illinois at Chicago, Chicago, IL, USA

${ }^{4}$ Office of Research and Development, National Health and Environmental

Effects Research Laboratory, Environmental Public Health Division,

Epidemiology Branch, U.S. Environmental Protection Agency, Research

Triangle Park, NC, USA

Full list of author information is available at the end of the article
} 


\section{Background}

Worldwide, gastrointestinal infections are a major, and often preventable, cause of mortality. In much of the developing world, mortality due to gastrointestinal infections disproportionately impacts children and is often associated with poor hygienic conditions (e.g., contaminated food or water and person-to-person transmission) [1]. In contrast, in the United States the elderly have a higher mortality rate due to gastrointestinal infections [2,3]. Trends in gastroenteritis-associated mortality are changing over time [4]. These changes may be due to several factors including the development of antibiotic resistant strains of certain pathogens, changing healthcare practices, the prevalence of immunosuppressive conditions, and demographic changes such as a growing elderly population.

Rates of enteric infection and mortality due to enteric infections steadily dropped during the 20th century due to disinfection of drinking water and improved hygiene practices. However, in the 1990 s and early 2000 s, mortality rates in the United States began to increase [2,3]. This is consistent with a rising proportion of Americans at increased risk for severe consequences due to enteric infections, including the elderly and those that are immunocompromised [5,6]. Data from the Foodborne Diseases Active Surveillance Network (FoodNet), which collects data for 10 U.S. states, together with passive surveillance data were used to estimate that 31 major pathogens cause 1,351 deaths (90\% CrI 712-2,268) annually [7]. In addition, an estimated 1,686 deaths (90\% CrI 3693,338 ) annually are due to foodborne illness from unspecified pathogenic agents [8]. This represents only a fraction of all deaths due to enteric infections which can also occur through waterborne and person-to-person transmission. Improved diagnostics, accuracy, and completeness of coding for deaths due to enteric infections may be causes for the demonstrated increasing trend.

Mortality records are coded using the International Classification of Disease (ICD), which was recently modified. In 1999, coding for mortality changed from using the ICD-9 scheme to ICD-10. The ICD-10 system is more detailed with approximately 8,000 categories for disease classification compared to about 5,000 categories in the ICD-9 system [9]. Few studies have demonstrated that the changes from ICD-9 to ICD-10 coding can affect trends in mortality. A study in Italy demonstrated that there was little variability between the two schemes for the larger disease groups, such as diseases of the circulatory system, however, the variability was higher for 'minor' disease groups such as infectious diseases and respiratory diseases [10]. A study focusing on respiratory disease mortality in the United Kingdom demonstrated that there was a $22 \%$ decrease in deaths assigned to respiratory disease under the ICD-10 coding scheme [11]. In the Southeastern United States, a study found that the change to ICD10 underestimated mortality due to heart disease and cerebrovascular disease and overestimates deaths due to diabetes [12]. In the U.S. it has been shown that implementing ICD-10 has variable effects on the discontinuity in trend; for some leading causes of death, such as influenza and pneumonia the discontinuity is substantial [13].

In this study we examine rates and trends in gastroenteritis-associated mortality for a 21-year period from 1985 to 2005 , during which the ICD-10 coding scheme, was implemented by categories of pathogens (viral, bacterial, protozoal). The ICD-10 coding scheme differs in several aspects from the ICD-9 scheme, including more detailed classification. Of importance for this study, coding rules and rules for selecting the underlying cause of death have been changed in the ICD-10 system [13]. Therefore, in this paper our analysis is stratified based on the ICD system used and assesses changes in ICD coding on gastroenteritis associated mortality.

\section{Methods \\ Data}

We conducted a population-based, descriptive study of data from the National Center for Health Statistics (NCHS) Multiple Cause of Death Mortality database for the years 1985-2005 [14]. We utilized individual level data for which we obtained a data use agreement from NCHS. The data use agreement was only for the period 1985-2005 therefore, we were not able to consider out years. Each entry includes demographic and residence information for the decedent as well as the underlying cause of death and up to 20 contributing conditions which are listed on the death certificate. The cause of death and conditions are coded using the International Classification of Diseases (ICD) codes. We abstracted all deaths for which the underlying cause or any contributing cause of death included gastrointestinal infection. Deaths prior to 1999 were coded using the International Classification of Diseases, Ninth Revision (ICD-9) codes. We abstracted records with the following codes listed for underlying cause or a contributing cause of death: 001-009, 041, 047, 070, 074, 079, 127, and 558. From 1999-2005, deaths were coded using the International Classification of Diseases and Related Health Problems, Tenth Revision (ICD-10) codes. We selected the records with the following gastrointestinal conditions listed: A00.0-09, A08, A87, B15, B08.4, B34.1, B77-79, B81-82, B95-97, and K52.

We calculated cause-specific mortality rates for gastrointestinal illness from 1985 - 2005 by grouping deaths into five broad pathogen categories (bacterial, viral, protozoal, unknown noninfectious, and unknown infectious). The specific ICD-9 and ICD-10 codes included in each category are provided in Table 1. For the bacterial group, analysis was considered with and without records of deaths due to 
Table 1 Specific ICD-9 and ICD-10 codes included in each category of gastroenteritis-associated mortality

\begin{tabular}{lll}
\hline & ICD-9 & ICD-10 \\
\hline Bacterial & $001-005,008.0-008.5,041$ & $A 00.0, A 01.00, A 01.1-A 01.4, A 02.0-02.1, A 02.20, A 02.8-A 02.9$, \\
& & $A 03.0-A 03.3, A 03.8-A 03.9, A 05.0-A 05.2, A 05.8-A 05.5, A 05.8-A 05.9$, \\
Viral & & $A 04, A 28.2, A 49.1-A 49.3, A 49.9, B 95.0-B 95.8, B 96.1-B 96.7$, \\
& $B 96.81-B 996.82, B 96.89$
\end{tabular}

Clostridium difficile (ICD9: 008.45, ICD10: A04.7) because this infection contributed $51.7 \%$ of cases and will drive the results for this category. Population estimates for each year were obtained from the U.S. Bureau of Census [15] and were used to calculate rates. The mortality data from the NCHS was linked to population estimates from the Census Bureau by age, race, gender, and regions. Race was categorized as White, Black, and Other. Age was classified into 8 increments $(0-4,5-24,25-34,35-44,45-54,55-64$,
65-74, and over 75. Region was defined by the U.S. census as Northeast, Midwest, South, and West [15]. All deaths occurring outside of the United States were excluded from the analysis.

\section{Analysis}

We examined the trends in gastroenteritis-associated mortality using age-adjusted rates of mortality, calculated by direct standardization [16] with the 2000 U.S. population

Table 2 Prevalence and record placement of gastroenteritis as a cause of death

\begin{tabular}{|c|c|c|c|c|c|c|c|c|c|}
\hline \multirow[t]{2}{*}{ Year } & \multirow{2}{*}{$\begin{array}{l}\text { Total no. } \\
\text { of deaths } \\
\text { related to GI }\end{array}$} & \multirow{2}{*}{$\begin{array}{l}\text { Total no. } \\
\text { of deaths }\end{array}$} & \multirow{2}{*}{$\begin{array}{l}\% \text { of deaths } \\
\text { related to } \\
\text { Gl infection }\end{array}$} & \multicolumn{6}{|c|}{ Placement of diagnosis for gastroenteritis in mortality record deaths } \\
\hline & & & & $\begin{array}{l}\text { Underlying } \\
\text { cause }\end{array}$ & $\begin{array}{l}\text { Contributing } \\
\text { condition } 1\end{array}$ & $\begin{array}{l}\text { Contributing } \\
\text { condition } 2\end{array}$ & $\begin{array}{l}\text { Contributing } \\
\text { condition } 3\end{array}$ & $\begin{array}{l}\text { Contributing } \\
\text { condition } 4\end{array}$ & $\begin{array}{l}\text { Contributing } \\
\text { condition } 5 \\
\text { or greater }\end{array}$ \\
\hline 1985 & 5265 & 2089378 & 0.25 & 2229 & 2083 & 870 & 1007 & 716 & 637 \\
\hline 1986 & 5386 & 2108384 & 0.26 & 2216 & 2107 & 886 & 1053 & 786 & 582 \\
\hline 1987 & 5609 & 2126342 & 0.26 & 2295 & 2205 & 926 & 1118 & 800 & 588 \\
\hline 1988 & 6054 & 2171196 & 0.28 & 2484 & 2280 & 988 & 1188 & 930 & 698 \\
\hline 1989 & 6791 & 2153859 & 0.32 & 2776 & 2653 & 1165 & 1195 & 972 & 857 \\
\hline 1990 & 6978 & 2151890 & 0.32 & 2744 & 2776 & 1154 & 1252 & 991 & 853 \\
\hline 1991 & 7172 & 2173060 & 0.33 & 2839 & 2865 & 1320 & 1320 & 936 & 792 \\
\hline 1992 & 7250 & 2179187 & 0.33 & 2775 & 2884 & 1359 & 1309 & 941 & 826 \\
\hline 1993 & 7531 & 2271947 & 0.33 & 2742 & 3033 & 1376 & 1335 & 985 & 874 \\
\hline 1994 & 7706 & 2282288 & 0.34 & 2839 & 3100 & 1469 & 1423 & 993 & 815 \\
\hline 1995 & 7813 & 2315251 & 0.34 & 2969 & 3377 & 1417 & 1351 & 926 & 813 \\
\hline 1996 & 7611 & 2318212 & 0.33 & 2945 & 3379 & 1409 & 1201 & 924 & 782 \\
\hline 1997 & 7876 & 2317586 & 0.34 & 3202 & 3711 & 1346 & 1220 & 870 & 826 \\
\hline 1998 & 8097 & 2340708 & 0.35 & 3289 & 3879 & 1379 & 1221 & 925 & 784 \\
\hline 1999 & 9478 & 2394871 & 0.40 & 3865 & 5034 & 1306 & 1298 & 968 & 874 \\
\hline 2000 & 10477 & 2407193 & 0.44 & 3734 & 5328 & 2018 & 1240 & 959 & 958 \\
\hline 2001 & 10841 & 2419960 & 0.45 & 3959 & 5532 & 2133 & 1300 & 1015 & 889 \\
\hline 2002 & 12655 & 2446796 & 0.52 & 4921 & 6955 & 2282 & 1378 & 1060 & 1024 \\
\hline 2003 & 14029 & 2452154 & 0.57 & 5637 & 8349 & 2428 & 1306 & 961 & 1042 \\
\hline 2004 & 16466 & 2401400 & 0.69 & 7026 & 10286 & 2735 & 1424 & 973 & 1116 \\
\hline 2005 & 19589 & 2452506 & 0.80 & 8866 & 12515 & 3163 & 1650 & 1135 & 1233 \\
\hline $1985-2005$ & 190674 & 47974168 & 0.40 & & & & & & \\
\hline
\end{tabular}


as estimated by the Census Bureau as the standard, for each pathogen category separately. Records for 1985-1998, which use ICD-9 codes, and 1999-2005, which use ICD10 codes, were not directly comparable due to changes in coding and practices. Trends in annual age-adjusted mortality rates and percent of overall mortality due to gastroenteritis were assessed using a linear regression spline analysis to determine if there was a change in slope between the use of ICD-9 and ICD-10 coding.

The relative risks and $95 \%$ confidence intervals (CIs) for mortality due to gastroenteritis among all decedents in the U.S. between 1985 and 2005 were calculated using Poisson regression adjusted for age group, sex, race, and region. Analyses were conducted stratified by ICD usage.

All analyses were conducted using $\mathrm{R}$ software (version 2.14.1) and SAS software (version 9.2; SAS Institute, Cary NC).

\section{Results}

There were 190,674 deaths related to gastroenteritis in the U.S. from 1985-2005 with an average of 9,080 per year. During this time the percent of deaths related to gastroenteritis more than tripled, increasing from $0.25 \%$ to $0.80 \%$ of all deaths (Table 1 ). There was a slight upward trend in the percent of deaths related to gastroenteritis in 1999; from 1985 to 1998 the percent of gastroenteritis-associated mortality increased by $0.0054 \%$ $\left(\beta_{\text {pre1998 }}=0.0054\right.$ (95\% CI: $\left.\left.0.0017,0.0090\right)\right)$ annually and from 1999-2005 the annual increase was $0.0550 \%$ $\left(\beta_{\text {post1999 }}=0.0550 \quad(95 \%\right.$ CI: $\left.0.0154,0.1146)\right)$. This increase may be due to the change in coding practices from ICD-9 to ICD-10. For $66.6 \%(127,046$ of 190,674$)$ of records gastroenteritis-associated conditions were listed as the underlying cause of death or in the first two contributing conditions (Table 2).

The age adjusted rates demonstrate an increasing trend over time for overall mortality due to gastroenteritis and for most specific pathogen groups (Figure 1). Again we see an increase in rates in 1999 for overall mortality due to GI concurrent with the change in coding from ICD-9 to ICD-10 (Table 3). For all gastroenteritis-associated mortality there was an annual increase of 0.291 deaths per 100,000 from 1985 to 1998 which increased to 0.418 deaths per 100,000 annually from 1999 to 2005 . GI deaths due to bacterial infections increases demonstrate a steep increase after 1999; from 1985 to 1998 there was an increase in age adjusted rates of bacterial gastroenteritisassociated deaths of 0.052 per 100,000 annually which increased to 0.428 deaths annually for the period from 1999 to 2005. However, this increase is less steep when cases of C. difficile are excluded, increasing from 0.032 per 100,000 annually before 1998 to 0.130 per 100,000 after 1999. Rates of viral and unknown infectious gastroenteritis-associated deaths both decrease over time (Table 3). There were no temporal trends observed in rates of unknown noninfectious gastroenteritis-associated deaths.

Adjusted relative risks for gastroenteritis as a cause of death were calculated separately for years using ICD-9

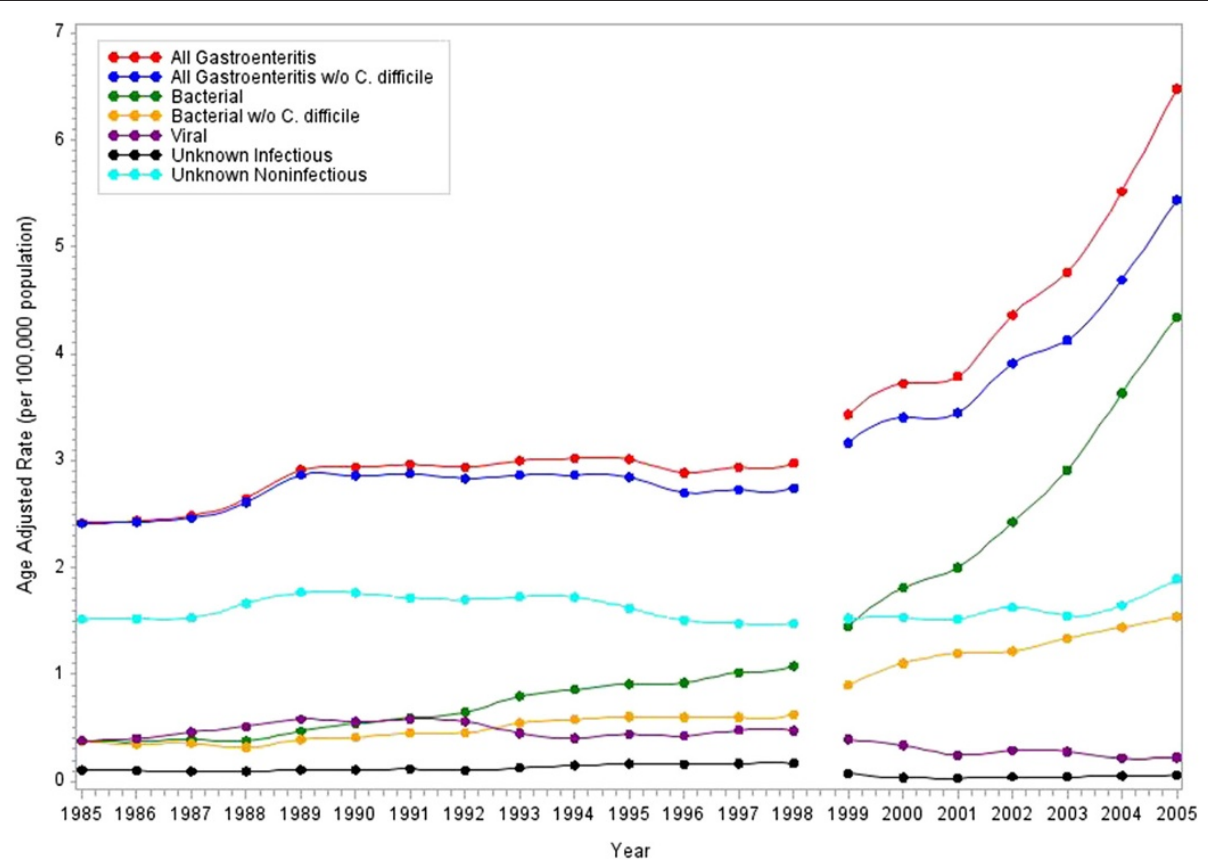

Figure 1 Age adjusted rates of gastroenteritis-associated mortality by year (per 100,000). The reference line at 1999 indicates when coding for mortality switched from ICD9 to ICD10. 
Table 3 Trend analysis for age adjusted rates of gastroenteritis-associated mortality

\begin{tabular}{llll}
\hline & Slope from 1985 - 1998 $\boldsymbol{\beta} \mathbf{( 9 5 \% ~ C l )}$ & Slope from 1999 - 2005 $\boldsymbol{\beta}(\mathbf{9 5 \%} \mathrm{Cl})$ & p-value (change in slope) \\
\hline All gastroenteritis & $0.029(0.001,0.057)$ & $0.418(0.105,0.883)$ & $<0.0001$ \\
All gastroenteritis w/o C. difficile & $0.016(-0.006,0.038)$ & $0.316(0.077,0.676)$ & $<0.0001$ \\
Bacterial & $0.052(0.035,0.069)$ & $0.428(0.099,0.850)$ & $<0.0001$ \\
Bacterial w/o C. difficile & $0.032(0.024,0.039)$ & $0.129(0.052,0.247)$ & $<0.0001$ \\
Viral & $-0.003(-0.010,0.005)$ & $-0.039(-0.055,0.018)$ & 0.0031 \\
Unknown infectious & $0.003(-0.001,0.007)$ & $-0.017(-0.007,-0.048)$ & 0.0011 \\
Unknown noninfectious & $-0.001(-0.023,0.004)$ & $0.0229(0.019,0.092)$ & $<0.0001$ \\
\hline
\end{tabular}

Slopes $(95 \% \mathrm{Cl})$ for periods 1985 to 1998 and 1999 to 2005 and p-value for the change in slope between the two time periods.

codes, 1985-1998 (Table 4), and ICD-10 codes, 19992005 (Table 5). For 1985-1998, the elderly, those over 75 years, were at the highest risk of death due to gastroenteritis in all categories except unknown infectious gastroenteritis in which children $0-4$ years of age were at the highest risk $(\mathrm{RR}=46.25(33.26,64.32)$ compared to those on the referent age category of 35-44) (Table 4). During this time period, blacks had an almost $50 \%$ increased risk of gastroenteritis-associated mortality than whites $(\mathrm{RR}=1.48(1.24,1.75))$; this trend was consistent for all categories of gastroenteritis. Males also had higher risks of gastroenteritis-associated mortality for every grouping compared to females.

For the years using ICD-10 coding, 1999-2005, again the highest adjusted relative risks were seen in the oldest age category (Table 5) for all gastroenteritis pathogen groups. While children aged 0-4 years demonstrated a risk over twice has high as those aged $35-44$ years (referent age category) $(\mathrm{RR}=2.49(1.14,5.47))$, this was much lower than the risk for this age group demonstrated during the years using ICD-9 coding. Though blacks had significantly higher risk of all gastroenteritis

Table 4 Adjusted relative risk $(95 \% \mathrm{CI})$ for gastroenteritis as a cause of death in the US, 1985-1998 (ICD9)

\begin{tabular}{|c|c|c|c|c|c|c|c|}
\hline & $\begin{array}{l}\text { All gastroenteritis } \\
\text { RR }(95 \% \mathrm{Cl})\end{array}$ & $\begin{array}{l}\text { All gastroenteritis } \\
\text { w/o C. difficile RR } \\
(95 \% \mathrm{Cl})\end{array}$ & $\begin{array}{l}\text { Bacterial RR } \\
(95 \% \mathrm{Cl})\end{array}$ & $\begin{array}{l}\text { Bacterial w/o } \\
\text { C. difficile RR } \\
(95 \% \mathrm{Cl})\end{array}$ & $\begin{array}{l}\text { Viral RR } \\
(95 \% \mathrm{Cl})\end{array}$ & $\begin{array}{l}\text { Unknown } \\
\text { infectious } \\
\text { RR }(95 \% \mathrm{Cl})\end{array}$ & $\begin{array}{l}\text { Unknown } \\
\text { noninfectious } \\
\text { RR }(95 \% \mathrm{Cl})\end{array}$ \\
\hline \multicolumn{8}{|l|}{ Age group } \\
\hline $0-4$ & $2.33(1.66,3.26)$ & $2.37(1.69,3.31)$ & $1.34(1.03,1.74)$ & $1.48(1.19,1.84)$ & $0.88(0.70,1.10)$ & $46.25(33.26,64.32)$ & $1.68(1.14,2.48)$ \\
\hline $5-24$ & $0.14(0.11,0.19)$ & $0.15(0.11,0.19)$ & $0.16(0.12,0.21)$ & $0.18(0.13,0.23)$ & $0.15(0.12,0.19)$ & $0.22(0.14,0.35)$ & $0.13(0.09,0.18)$ \\
\hline $25-34$ & $0.58(0.40,0.85)$ & $0.58(0.40,0.85)$ & $0.60(0.44,0.82)$ & $0.61(0.46,0.81)$ & $0.52(0.40,0.68)$ & $0.50(0.32,0.78)$ & $0.61(0.37,0.99)$ \\
\hline $35-44$ & referent & referent & referent & referent & referent & referent & referent \\
\hline $45-54$ & $1.41(1.03,1.92)$ & $1.41(1.03,1.92)$ & $1.63(1.25,2.12)$ & $1.65(1.31,2.08)$ & $1.36(1.05,1.75)$ & $1.67(1.15,2.44)$ & $1.38(0.96,1.99)$ \\
\hline $55-64$ & $3.02(2.28,3.99)$ & $3.00(2.27,3.96)$ & $3.62(2.84,4.61)$ & $3.46(2.83,4.25)$ & $2.36(1.89,2.94)$ & $3.83(2.74,5.34)$ & $3.36(2.4,4.71)$ \\
\hline $65-74$ & $8.02(6.10,10.54)$ & $7.86(5.99,10.33)$ & $10.06(8.07,12.54)$ & $8.70(7.20,10.51)$ & $4.73(3.88,5.77)$ & $9.76(6.97,13.67)$ & $10.06(7.20,14.07)$ \\
\hline $75+$ & $30.93(23.34,40.99)$ & $29.99(22.62,39.76)$ & $39.54(31.60,49.48)$ & $29.88(24.53,36.40)$ & $12.51(9.99,15.65)$ & $32.67(22.66,47.11)$ & $43.71(31.15,61.32)$ \\
\hline \multicolumn{8}{|l|}{ Race } \\
\hline White & referent & referent & referent & referent & referent & referent & referent \\
\hline Black & $1.48(1.24,1.75)$ & $1.49(1.26,1.77)$ & $1.67(1.46,1.91)$ & $1.93(1.72,2.15)$ & $1.45(1.22,1.72)$ & $3.06(2.47,3.79)$ & $1.23(1.03,1.48)$ \\
\hline Other & $0.77(0.67,0.88)$ & $0.77(0.68,0.89)$ & $0.86(0.73,1.03)$ & $1.01(0.83,1.23)$ & $1.07(0.90,1.28)$ & $0.84(0.67,1.05)$ & $0.56(0.49,0.65)$ \\
\hline \multicolumn{8}{|l|}{ Gender } \\
\hline Male & $1.20(1.10,1.31)$ & $1.20(1.09,1.31)$ & $1.44(1.34,1.56)$ & $1.55(1.44,1.67)$ & $1.39(1.25,1.54)$ & $1.23(1.04,1.45)$ & $1.04(0.96,1.12)$ \\
\hline Female & referent & referent & referent & referent & referent & referent & referent \\
\hline \multicolumn{8}{|l|}{ Region } \\
\hline Northeast & $1.10(0.96,1.27)$ & $1.07(0.93,1.22)$ & $1.62(1.42,1.85)$ & $1.47(1.31,1.63)$ & $0.75(0.63,0.89)$ & $1.03(0.86,1.22)$ & $1.13(0.99,1.28)$ \\
\hline Midwest & $1.00(0.87,1.15)$ & $0.99(0.86,1.14)$ & $1.22(1.12,1.34)$ & $1.25(1.13,1.39)$ & $0.60(0.52,0.70)$ & $1.02(0.83,1.25)$ & $1.10(0.96,1.26)$ \\
\hline South & $1.04(0.93,1.18)$ & $1.05(0.93,1.19)$ & $1.44(1.31,1.57)$ & $1.77(1.57,1.99)$ & $0.71(0.63,0.79)$ & $1.14(0.94,1.37)$ & $1.04(0.92,1.18)$ \\
\hline West & referent & referent & referent & referent & referent & referent & referent \\
\hline
\end{tabular}


Table 5 Adjusted relative risk $(95 \% \mathrm{Cl})$ for gastroenteritis as a cause of death in the US, 1999-2005 (ICD10)

\begin{tabular}{|c|c|c|c|c|c|c|c|}
\hline & $\begin{array}{l}\text { All gastroenteritis } \\
\text { RR }(95 \% \mathrm{Cl})\end{array}$ & $\begin{array}{l}\text { All gastroenteritis } \\
\text { w/o C. difficile RR } \\
\text { ( } 95 \% \text { Cl) }\end{array}$ & $\begin{array}{l}\text { Bacterial RR } \\
(95 \% \mathrm{Cl})\end{array}$ & $\begin{array}{l}\text { Bacterial w/o } \\
\text { C. difficile RR } \\
(95 \% \mathrm{Cl})\end{array}$ & $\begin{array}{l}\text { Viral RR } \\
(95 \% \mathrm{Cl})\end{array}$ & $\begin{array}{l}\text { Unknown } \\
\text { infectious } \\
\text { RR ( } 95 \% \mathrm{Cl})\end{array}$ & $\begin{array}{l}\text { Unknown } \\
\text { noninfectious } \\
\text { RR }(95 \% \mathrm{Cl})\end{array}$ \\
\hline \multicolumn{8}{|l|}{ Age group } \\
\hline $0-4$ & $2.00(1.57,2.53)$ & $2.09(1.67,2.62)$ & $0.78(0.62,0.98)$ & $0.86(0.72,1.02)$ & $2.94(2.44,3.54)$ & $2.49(1.14,5.47)$ & $3.90(2.80,5.45)$ \\
\hline $5-24$ & $0.18(0.15,0.22)$ & $0.18(0.15,0.23)$ & $0.14(0.11,0.17)$ & $0.14(0.12,0.16)$ & $0.28(0.23,0.34)$ & $0.29(0.13,0.66)$ & $0.20(0.15,0.27)$ \\
\hline $25-34$ & $0.43(0.33,0.55)$ & $0.43(0.34,0.54)$ & $0.44(0.35,0.55)$ & $0.45(0.38,0.53)$ & $0.40(0.32,0.51)$ & $0.69(0.29,1.65)$ & $0.42(0.29,0.60)$ \\
\hline $35-44$ & referent & referent & referent & referent & referent & referent & referent \\
\hline $45-54$ & $2.22(1.76,2.81)$ & $2.21(1.77,2.77)$ & $2.58(2.08,3.20)$ & $2.49(2.20,2.83)$ & $1.90(1.48,2.43)$ & $2.67(1.40,5.10)$ & $2.14(1.66,2.75)$ \\
\hline $55-64$ & $5.17(4.24,6.31)$ & $4.99(4.13,6.03)$ & $6.57(5.45,7.92)$ & $5.57(4.98,6.24)$ & $2.11(1.71,2.60)$ & $7.01(3.82,12.86)$ & $5.76(4.58,7.24)$ \\
\hline $65-74$ & $14.44(12.01,17.35)$ & $13.36(11.21,15.91)$ & $18.40(15.53,21.82)$ & $12.24(10.98,13.65)$ & $3.30(2.83,3.85)$ & $27.63(15.52,49.19)$ & $17.79(14.25,22.21)$ \\
\hline $75+$ & $61.72(51.11,74.55)$ & $56.06(46.76,67.21)$ & $75.98(63.97,90.26)$ & $37.96(34.10,42.25)$ & $11.72(9.57,14.36)$ & $112.85(63.63,200.16)$ & $83.16(66.31,104.29)$ \\
\hline \multicolumn{8}{|l|}{ Race } \\
\hline White & referent & referent & referent & referent & referent & referent & referent \\
\hline Black & $1.31(1.13,1.52)$ & $1.37(1.18,1.59)$ & $1.49(1.30,1.71)$ & $2.39(2.21,2.58)$ & $1.51(1.25,1.83)$ & $1.09(0.85,1.38)$ & $0.97(0.81,1.17)$ \\
\hline Other & $0.52(0.47,0.58)$ & $0.55(0.49,0.61)$ & $0.53(0.46,0.60)$ & $0.75(0.66,0.84)$ & $0.84(0.71,0.98)$ & $0.31(0.17,0.56)$ & $0.42(0.38,0.48)$ \\
\hline \multicolumn{8}{|l|}{ Gender } \\
\hline Male & $1.06(0.99,1.13)$ & $1.05(0.98,1.12)$ & $1.16(1.09,1.23)$ & $1.34(1.27,1.41)$ & $1.30(1.14,1.49)$ & $0.89(0.81,0.99)$ & $0.87(0.82,0.93)$ \\
\hline Female & referent & referent & referent & referent & referent & referent & referent \\
\hline \multicolumn{8}{|l|}{ Region } \\
\hline Northeast & $1.22(1.10,1.34)$ & $1.16(1.05,1.29)$ & $1.42(1.30,1.56)$ & $1.23(1.12,1.35)$ & $0.82(0.66,1.03)$ & $1.30(1.12,1.5)$ & $1.02(0.93,1.12)$ \\
\hline Midwest & $1.18(1.07,1.30)$ & $1.13(1.01,1.25)$ & $1.27(1.18,1.37)$ & $1.00(0.94,1.05)$ & $0.86(0.71,1.04)$ & $1.12(0.95,1.3)$ & $1.13(1.02,1.26)$ \\
\hline South & $0.99(0.92,1.07)$ & $0.98(0.91,1.06)$ & $1.05(1.00,1.12)$ & $0.98(0.93,1.02)$ & $0.77(0.68,0.88)$ & $1.08(0.97,1.2)$ & $0.96(0.88,1.04)$ \\
\hline West & referent & referent & referent & referent & referent & referent & referent \\
\hline
\end{tabular}

as a cause of death $(R R=1.31(1.13,1.52))$, the risk of death related to an unknown pathogen was no higher than that of whites. Risk was significantly higher in males for bacterial and viral deaths $(\mathrm{RR}=1.16(1.09,1.23)$ and $1.34(1.27,1.41)$ respectively); however they were less likely to have unknown pathogen documented as a cause of death.

\section{Discussion}

Over the 21-year period from 1985-2005 we estimated that an average of 9,080 deaths per year were due to gastrointestinal disease as an underlying cause or contributing factor. The number and percentage of deaths due to gastroenteritis demonstrated a steady increasing trend over the time period, even after adjusting for age. We demonstrated a significant increase in slope from a 0.0054\% annual increase during the period 1985-1998, when ICD-9 coding was used, to a $0.0550 \%$ annual increase during 1999-2005, when ICD-10 coding was used. Though the analysis was limited by differing lengths of time for ICD-9 and ICD-10 usage, our analysis has shed light on the incompatibility between ICD-9 and ICD-10 coding practices for gastrointestinal diseases. ICD-10 coding requires an additional infection code to identify the specific pathogen as the cause of disease [17]. For some bacterial pathogens, such as streptococcus and staphylococcus, this pathogen specific code was not provided and these were grouped in broader bacterial categories. In addition, the guidance on the coding for unknown infectious and non-infectious GI varies from ICD-9 and ICD-10.

Gastroenteritis is typically considered a secondary infection and not the primary reason for hospitalization or death. However, we found gastroenteritis to be listed as the underlying cause of death or in the first two contributing conditions for the majority of records in both the ICD-9 and ICD-10 coding. The consistent increase over time and recording of gastroenteritis as a cause of death suggest an increase in coding and recognition of gastroenteritis as a cause of mortality by physicians. Improved diagnosis and testing methodology for gastroenteritis may also contribute to the increase in reporting of gastroenteritis-associated deaths.

The increase in gastroenteritis-associated mortality is primarily driven by an increase in reporting of bacterial infections. This trend remained even with the removal of the ICD codes for Clostridium difficile (ICD9: 008.45, ICD10: A04.7), which represented over $50 \%$ of deaths in 
the bacterial pathogen group. Recently, understanding the trends in gastrointestinal-associated mortality in the U.S. has been complicated due to the dramatic increase in $C$. difficile. Deaths due to $C$. difficile, primarily a nosocomial infection [18], contributed a majority of deaths and drove the results for bacterial-associated mortality, therefore trends were analyzed both with and without this cause. The increasing burden of mortality due to C. difficile has been well documented; with studies estimating a 5-fold increase due to $C$. difficile [4] and demonstrating an increase from 5.7 per million population in 1999 to 23.7 per million population in 2004 [19].

As expected, the elderly, 65 years and above, were at the highest risk of gastroenteritis-associated death for both the ICD-9 and ICD-10 coding periods. Gastroenteritis is often a complication of conditions which affect the elderly population, however, as noted, for the majority of cases gastroenteritis was indicated as the underlying cause or one of the primary causes of death. The aging population in the U.S. leads to more people with increased vulnerability to GI infections due to compromised immune systems $[5,6,20]$. We also found that blacks had a higher risk for death due to gastroenteritis compared to whites after adjustment for age. This increased risk maybe due delayed treatment of disease $[21,22]$.

Our analysis has clinical implications as it demonstrates a lack of testing for specific gastrointestinal pathogens. Age adjusted rates for the unknown noninfectious disease category were higher than both the bacterial (w/o C. difficle) and viral categories. For 1985-1998, the youngest age group, $0-4$ years, demonstrated the highest risk for the unknown infectious disease group. While this risk decreased for the years using ICD-10 coding it was still 2.5 times higher than the reference age group, 35-44 years. The ICD-10 time period also demonstrated a high relative risk, almost 4 times that of the reference group, for the unknown noninfectious disease group. Both the unknown infectious and unknown non-infectious disease groups are non-specific diagnosis codes which are used when specific pathogen testing has not been conducted. A study analyzing the seasonal patterns of these non-specific disease categories suggests that these may be due to viral pathogens [23]. However, increased awareness by clinicians of the need for laboratory testing for specific gastrointestinal pathogens would help to assess the mortality risk due to specific pathogens.

The viral pathogen group demonstrated a decreasing risk over time whereas the bacterial pathogen group demonstrated an increase over time. This increase was primarily driven by the bacterial pathogen, $C$. difficile. However, there was an increase even with the removal of the diagnosis code for $C$. difficile and maybe due to the increase in antibiotic resistant pathogens $[24,25]$.

\section{Conclusion}

In summary, the percent gastroenteritis-associated deaths tripled from 1985 to 2005. In 1999, ICD-10 coding was introduced for mortality and our analysis demonstrated a significant change in annual increase for the period using ICD-9 and that using ICD-10 coding. Those over 65 years of age were at the highest risk of reporting gastroenteritis as a cause of death for both coding practices. Overall, the black population is at the highest risk gastroenteritisassociated mortality. While mortality due to viral pathogens has been decreasing the deaths due to bacterial pathogens has increased. Gastroenteritis remains an important cause of mortality in the United States.

\section{Abbreviations}

C. difficile: Clostridium difficile; GI: Gastrointestinal; ICD: International Classification of Diseases; ICD-9: International Classification of Diseases, Ninth Revision; ICD-10: International Classification of Diseases and Related Health Problems, Tenth Revision.

\section{Competing interests}

The authors declare that they have no competing interests.

\section{Authors' contributions}

JSJ and TJW conceptualized and provided guidance on the study and analysis. JES abstracted data from the original mortality database. GSS and JSJ conducted the analysis. All authors read and approved the final manuscript.

\section{Acknowledgements}

The authors would like to thank Danelle Lobdell for review of this manuscript.

\section{Disclaimer}

The views expressed in this article are those of the authors and do not necessarily reflect the views or policies of the U.S. Environmental Protection Agency. Mention of trade names or commercial products does not constitute endorsement or recommendation for use.

\section{Author details}

'School of Public Health, Division of Environmental and Occupational Health Sciences, University of Illinois at Chicago, Chicago, IL, USA. ${ }^{2}$ Gillings School of Global Public Health, Department of Epidemiology, University of North Carolina at Chapel Hill, Chapel Hill, NC, USA. ${ }^{3}$ Office of Research and Development, National Health and Environmental Effects Research Laboratory, Research Cores Unit, U.S. Environmental Protection Agency, Research Triangle Park, NC, USA. ${ }^{4}$ Office of Research and Development, National Health and Environmental Effects Research Laboratory, Environmental Public Health Division, Epidemiology Branch, U.S. Environmental Protection Agency, Research Triangle Park, NC, USA.

\section{Received: 30 April 2014 Accepted: 3 December 2014}

\section{- -20}

\section{References}

1. Black RE, Cousens S, Johnson HL, Lawn JE, Rudan I, Bassani DG, Jha P, Campbell H, Walker CF, Cibulskis R, Eisele T, Liu L, Mathers C, Child Health Epidemiology Reference Group of WHO and UNICEF: Global, regional, and national causes of child mortality in 2008: a systematic analysis. Lancet 2010, 375(9730):1969-1987.

2. Lew JF, Glass Rl, Gangarosa RE, Cohen IP, Bern C, Moe CL: Diarrheal deaths in the United States, 1979 through 1987. A special problem for the elderly. JAMA 1991, 265(24):3280-3284.

3. Peterson CA, Calderon RL: Trends in enteric disease as a cause of death in the United States, 1989-1996. Am J Epidemiol 2003, 157(1):58-65.

4. Hall AJ, Curns AT, McDonald LC, Parashar UD, Lopman BA: The roles of Clostridium difficile and norovirus among gastroenteritis-associated deaths in the United States, 1999-2007. Clin Infect Dis 2012, 55(2):216-223. 
5. United States Census Bureau: $65+$ in the United States. Current Population Reports, Special Studies. Washington, DC: U.S. Bureau of the Census; 2005.

6. Wiener JM, Tilly J: Population ageing in the United States of America: implications for public programmes. Int J Epidemiol 2002, 31(4):776-781.

7. Scallan E, Hoekstra RM, Angulo FJ, Tauxe RV, Widdowson MA, Roy SL, Jones JL, Griffin PM: Foodborne illness acquired in the United States-major pathogens. Emerg Infect Dis 2011, 17(1):7-15.

8. Scallan E, Griffin PM, Angulo FJ, Tauxe RV, Hoekstra RM: Foodborne illness acquired in the United States-unspecified agents. Emerg Infect Dis 2011, 17(1):16-22.

9. Centers for Disease Control and Prevention (CDC): Preliminary foodnet data on the incidence of infection with pathogens transmitted commonly through food - 10 states, 2009. MMWR Morb Mortal Wkly Rep 2010, 59(14):418-422.

10. Brocco S, Vercellino P, Goldoni CA, Alba N, Gatti MG, Agostini D, Autelitano M, Califano A, Deriu F, Rigoni G, Cassinadri MT, Garrone E: ICD-9, ICD-10 and effects on mortality statistics. Epidemiologia e prevenzione, 34(3):109-119.

11. Brock $A$, Griffiths $C$, Rooney $C$ : The impact of introducing ICD-10 on analysis of respiratory mortality trends in England and Wales. Health Stat Q Off Natl Stat 2006, 29:9-17.

12. Joyner-Grantham J, Simmons DR, Moore MA, Ferrario CM: The impact of changing ICD code on hypertension-related mortality in the southeastern United States from 1994-2005. J Clin Hypertens 12(3):213-222.

13. Anderson RN, Minino AM, Hoyert DL, Rosenberg HM: Comparability of cause of death between ICD-9 and ICD-10: preliminary estimates. Natl Vital Stat Rep 2001, 49(2):1-32.

14. National Center for Health Statistics (NCHS): Mortality data, multiple causeof-death public-use data files. Hyattsville, Maryland; 2012.

15. United States Census Bureau: US population estimates by age, sex, race, and Hispanic origin: 1980 to 1998. Washington, DC: Bureau of the Census, US Department of Commerce; 2000.

16. Rothman K, Greenland S, Lash TL: Modern Epidemiology. 3rd edition. Philadelphia, PA: Lippincott Williams and Wilkins; 2008.

17. Centers for Disease Control and Prevention (CDC): ICD-10-CM Official Guidelines for Coding and Reporting. 2012

18. Barbut F, Petit JC: Epidemiology of Clostridium difficile-associated infections. Clin Microbiol Infect 2001, 7(8):405-410.

19. Redelings MD, Sorvillo F, Mascola L: Increase in Clostridium difficile-related mortality rates, United States, 1999-2004. Emerg Infect Dis 2007, 13(9):1417-1419.

20. Gerba CP, Rose JB, Haas CN: Sensitive populations: who is at the greatest risk? Int J Food Microbiol 1996, 30(1-2):113-123.

21. Fiscella K, Franks P, Doescher MP, Saver BG: Disparities in health care by race, ethnicity, and language among the insured: findings from a national sample. Med Care 2002, 40(1):52-59.

22. Hargraves $\mathrm{JL}$, Cunningham PJ, Hughes RG: Racial and ethnic differences in access to medical care in managed care plans. Health Serv Res 2001, 36(5):853-868

23. Chui KK, Jagai JS, Griffiths JK, Naumova EN: Hospitalization of the elderly in the United States for nonspecific gastrointestinal diseases: a search for etiological clues. Am J Public Health 2011, 101(11):2082-2086.

24. Cassell GJM: Development of antimicrobial agents in the era of new and reemerging infectious diseases and increasing antibiotic resistance. JAMA 2001, 285(5):601-605.

25. Hellinger WC: Confronting the problem of increasing antibiotic resistance. South Med J 2000, 93(9):842-848.

\section{Submit your next manuscript to BioMed Central and take full advantage of:}

- Convenient online submission

- Thorough peer review

- No space constraints or color figure charges

- Immediate publication on acceptance

- Inclusion in PubMed, CAS, Scopus and Google Scholar

- Research which is freely available for redistribution

Submit your manuscript at www.biomedcentral.com/submit
Ciomed Central 